\title{
Eksistensi Perempuan Dalam Transformasi Sosial ( Studi di PT. Multi Usaha Raya Kabupaten Sorong )
}

\author{
Rasna $^{1}$, Nur Hidaya ${ }^{2}$ \\ ${ }^{12}$ Program Studi Sosiologi, FISIP,Universitas Muhammadiyah Sorong, Indonesia \\ Email : nurhidaya@gmail.com
}

\begin{abstract}
ABSTRAK
Penelitian ini bertujuan : a) Untuk mengetahui eksistensi perempuan dalam transformasi sosial di PT. Multi Usaha Raya kabupaten Sorong. b) Untuk mengetahui yang melatar belakangi perempuan bekerja di PT. Multi Usaha Raya kabupaten Sorong. Metode yang akan digunakan adalah metode penelitian kualitatif deskriptif yaitu metode penelitian yang memerlukan data berupa kata-kata atau kalimat secara lisan ataupun tulisan serta data perilaku yang dapat diamati. Jenis penelitian yang digunakan penelitian terapan dan penelitian dasar atau murni. populasi dalam penelitian ini seluruh karyawan perempuan pada PT. Multi Usaha Raya di kabupaten Sorong. sedangkan teknik penarikan sampel dengan mengunakan metode random sampling yaitu sebagian karyawan perempuan pada PT. Multi Usaha Raya yang di anggap mewakili populasi. Teknik pengumpulan data menggunakan wawancara, observasi dan dokumentasi. analisa data yang digunakan adalah analisis deskriptif kualitatif secara analitik. Hasil penelitian menunjukkan bahwa hampir seluruh karyawan perempuan di perusahaan PT. Multi Usaha Raya merupakan ibu rumah tangga. Meski harus bekerja perannya sebagai istri dan ibu dalam keluarga tidak mereka abaikan, dari dini hari mereka sudah harus bangun untuk menyiapkan seluruh keperluan suaminya sebelum berangkat bekerja dan anaknya sebelum berangkat sekolah seperti menyiapkan pakaian seragam dan sarapan untuk anak dan suaminya, setelah itu membersihkan rumah lalu mulai untuk berangkat kerja pagi harinya hingga petang demi keluarga mereka.
\end{abstract}

Kata Kunci : Eksistensi Perempuan, Transformasi Sosial, Kabupaten Sorong

\section{PENDAHULUAN}

Sejarah umat manusia menempatkan perempuan sangat luhur Walaupun juga sejarah umat manusia telah menempatkan perempuan dalam jalan yang nista dan buruk. Iya, sejarah memang bukan linier. Akan tetapi ruh perempuan selalu menghiasi jalannya peradaban dengan penuh rasa. Bukan siapa-siapa dan bukan apa-apa yang dicari Adam ketika diciptakan Tuhan, tak lain adalah perempuan. Dari Hawa lah Adam mendapatkan kehidupan, sehingga perjalanan hidupnya di masa depan bias semakin sempurna lewat kehadiran anakanaknya. Hawa adalah ibu kehidupan bagi Adam.

Berbagai diskriminasi dan praktek kekerasan memperlihatkan peradaban

43 Eksistensi Perempuan dalam transformasi sosial.................. 


\section{Noken Volume 5 ( 1 ) Halaman : 43-52 2019}

yang "hanya" dibangun kaum pria lebih memungkinkan terjadi banyaknya kekerasan dan kebiadaban. Ideologi maskulinisme telah menjadikan peradaban penuh dengan onak dan duri, sehingga wajah peradaban terasa kusam dan menyeramkan. Praktek politik yang minus perempuan terasa sekali gampang melahirkan perang dan amarah. Karena nafsu kehidupan hanya diliputi dengan keinginan menang sendiri dan jaya sendiri.

Sebagai ibu kehidupan, tanggung jawab perempuan tidaklah gampang. Di tengah gejolak zaman yang penuh keganjilan dan kemunafikan saat itu, perempuan harus mampu menempatkan dirinya sebagai nafas kehidupan yang bias meniupkan kedamaian, ketentraman, dan keindahan. Ini bukan berarti hanya cukup dengan tampil cantik dan mempesona secara fisik (physicly), akan tetapi perempuan harus tampil di hadapan publik untuk menyuarakan gerakan kehidupan yang memihak kaum tertindas, menggugat kebiadaban, dan melanjutkan gerakan kemanusiaan yang terus membela rasa mengedepankan keadilan, cinta, dan kesetaraan. Oleh karena itu, problem eksistensi perempuan tetap aktual untuk terus di kaji para sosiolog, demi transformasi sosial kearah yang lebih baik.

Sesungguhnya pandangan terhadap perempuan semata-mata pada fisik tidak berubah dari masa lalu, bahkan semakin kokoh dengan adanya sistem kontemporer. Yang sempat di perhatikan adalah bahwa kesempatan perempuan yang memiliki keahlian dan pengetahuan dalam bekerja lebih sedikit dibandingkan kesempatan perempuan yang mempunyai kecantikan dan daya tarik.

Posisi perempuan yang demikian menarik untuk dikaji terutama pada buruh perempuan di PT. Multi Usaha Raya yang mengalami proses perubahan sosial yang signifikan akibat industrialisasi. terjadi pergeseran peran domestik perempuan ke publik pada buruh perempuan dengan tidak diikuti kesadaran gender. Buruh perempuan menguasai aset ekonomi, berperan dalam pengambilan keputusan, sedangkan laki-laki mengalami inferior maskulin dengan tidak ada kesempatan dalam pekerjaan. Buruh perempuan mengalami ekploitasi baru dengan upah yang rendah dan pemanfaatan buruh dengan pendidikan rendah. Perempuan dianggap mendominasi di ranah 


\section{Noken Volume 5 ( 1 ) Halaman : 43-52 2019}

domestik karena keunggulan aksesibilitas dan kesempatan pada dunia industri.

Penelitian ini bertujuan : a) Untuk mengetahui eksistensi perempuan dalam transformasi sosial di PT. Multi Usaha

\section{METODE}

\begin{abstract}
Metode yang akan digunakan adalah metode penelitian kualitatif deskriptif yaitu metode penelitian yang memerlukan data berupa kata-kata atau kalimat secara lisan ataupun tulisan serta data perilaku yang dapat diamati. Jenis penelitian yang digunakan penelitian terapan dan penelitian dasar atau murni. populasi dalam penelitian ini seluruh
\end{abstract}

\section{HASIL DAN PEMBAHASAN}

\section{Eksistensi Perempuan Dalam Transformasi Sosial di PT. Multi Usaha Raya Kabupaten Sorong}

\section{Perempuan Dalam Rumah Tangga}

Hasil penelitian menunjukkan bahwa hampir seluruh karyawan perempuan di perusahaan PT. Multi Usaha Raya merupakan ibu rumah tangga. Meski harus bekerja perannya sebagai istri dan ibu dalam keluarga tidak mereka abaikan, dari dini hari mereka sudah harus bangun untuk
Raya kabupaten Sorong. b) Untuk mengetahui yang melatar belakangi perempuan bekerja di PT. Multi Usaha Raya kabupaten Sorong

karyawan perempuan pada PT. Multi Usaha Raya di kabupaten Sorong. sedangkan teknik penarikan sampel dengan mengunakan metode random sampling yaitu sebagian karyawan perempuan pada PT. Multi Usaha Raya yang di anggap mewakili populasi. Teknik pengumpulan data menggunakan wawancara, observasi dan dokumentasi. analisa data yang digunakan adalah analisis deskriptif kualitatif secara analitik.

menyiapkan seluruh keperluan suaminya sebelum berangkat bekerja dan anaknya sebelum berangkat sekolah seperti menyiapkan pakaian seragam dan sarapan untuk anak dan suaminya, setelah itu membersihkan rumah lalu mulai untuk berangkat kerja pagi harinya hingga petang demi keluarga mereka. seperti tidak ada kata lelah bagi mereka bilamana pada waktu libur kerja, mereka juga punya rutinitas lain untuk mengisi waktu kosong mereka yaitu dengan mengikuti pengajian mingguan, berkebun membantu suami bahkan ada yang 


\section{Noken Volume 5 ( 1 ) Halaman : 43-52 2019}

berjualan untuk menambah penghasilan demi keluarga mereka.

\section{Perempuan Dalam Ruang Industri}

Perempuan mempunyai kelebihan yang unik di banding dengan laki-laki, seperti etos kerja tinggi, ulet, sabar dan teliti. Keterlibatan perempuan dalam usaha meningkatkan perekonomian keluarga tidak diragukan lagi. Perempuan yang hidup di daerah persawahan, mereka akan pergi ke sawah, jika berada di daerah yang ramai nuansa perdagangan, maka perempuan yang memenuhi pasar sebagai pedagang. jika dekat dengan kawasan industri, maka perempuan paling banyak menjadi karyawan. Ada beberapa penyebab perempuan ingin bekerja yaitu: a) untuk meningkatkan kesejahteraan ekonomi ataupun untuk memenuhi kebutuhan sekolah anak-anaknya, b) keinginan untuk memiliki teman yang lebih banyak, c) mengejar status, d) senang dengan pekerjaan.

Dari 20 responden di PT. Multi Usaha Raya Kabupaten Sorong, penulis mendeskripsikan data dari hasil wawancara seperti yang telah di uraikan di atas. Adapun hasil wawancara dari 20 responden itu yang merupakan salah satu pimpinan perusahan yaitu Bapak Manager personalia dan karyawati buruh pabrik kayu lapis yang merupakan ibu rumah tangga, di PT. Multi Usaha Raya Kabupaten Sorong, namun penulis hanya mengambil keterangan dari beberapa keterwakilan responden karyawati, karena dari hasil data wawancara hampir sama jawaban-jawaban yang di dapat dari 20 responden tersebut.

Wawancara dengan Bapak Manager Personalia : "Sebagian besar dari para pekerja di PT. Multi Usaha Raya Kabupaten Sorong, yang memproduksi kayu lapis adalah ibu rumah tangga, usia para pekerja tersebut adalah 18-50 tahun, dan jumlah kariyawati di perusahaan tersebut adalah 96 orang, jumlah tersebut tak menetap karena adanya sistem kontrak kerja. Ada 3 kegiatan produksi yang banyak mempekerjakan perempuan yaitu, bagian penyusunan dan perbaikan venir, perekatan dan mengempaan kayu lapis, serta pengerjaan akhir kayu lapis”. (Tanggal 07 Januari 2019).

Wawancara dengan karyawati berinisial "Y" Seorang Ibu rumah tangga berusia 32 tahun. "Sebagai ibu rumah tangga yang memiliki dua orang anak, Membagi waktu merupakan hal penting, karena ibu "Y" berangkat kerja 07:00 pagi, jadi pada 


\section{Noken Volume 5 ( 1 ) Halaman : 43-52 2019}

dini hari pukul 04:00 ibu "Y" sudah harus bangun untuk mengurus kedua anak yang masih sekolah dan suami sebelum bekerja, seperti menyiapkan kebutuhan suami, kebutuhan anak sebelum berangkat sekolah, dan menyiapkan sarapan, alasan ibu "Y" bekerja karena kebutuhan ekonomi yang meningkat, jadi ibu harus bekerja untuk menambah penghasilan suami, selain itu ibu "Y" juga rutin ikut pengajian setiap hari minggu mengisi waktu libur kerjanya. (Tanggal 07 Januari 2019).

Wanwancara dengan karyawati berinisial "S" Seorang Ibu rumah tangga berusia 43 tahun. "Alasan saya bekerja agar punya penghasilan tetap karena suami saya hanya seorang petani yang penghasilannyapun kadang ada kadang tidak. Kata ibu "S". ibu "S" punya lahan perkebunan yang tidak begitu luas di manfaatkan untuk menanam sayuran seperti bayam, rica, dan tomat hasil panennya untuk kebutuhan sendiri dan di titipkan sebagian di tukang sayur untuk di jual, untuk cari uang jajan anak-anaknya saja kata si ibu "S". ibu "S" memiliki dua anak Laki-laki yang mandiri masih sekolah d bangku SMP dan satu lagi di SMA, di usia mereka yang masih anak-anak tapi mereka sudah bisa mengerjakan dan menyiapkan kebutuhan mereka sendiri dari sebelum sekolah sampai untuk makan sepulang sekolah jadi ibu " $\mathrm{S}$ " tidak repot dan khawatir untuk meninggalkan anaknya untuk bekerja. Selain bekerja ibu "S" juga ikut turut membantu suaminya berkebun di saat libur kerja". (Tanggal 07 Januari 2019).

Wawancara dengan kariyawati berinisial "TE" Seorang janda berusia 43 tahun. "Alasan ibu "TE" mau untuk bekerja adalah karena dialah tulang punggung dalam keluarga, ibu "TE" harus mengurus 3 orang anak yang masih sekolah. Setiap hari anak sulungnyalah yang menjaga adik-adiknya di saat ibu "TE" sedang bekerja, selain bekerja sebagai buruh, ibu "TE” juga berjualan kue seperti kue donat, panada dan bakpau di saat libur kerja. Rutinitas ini dia kerjakan sudah dua tahun setelah suaminya meninggal". (Tanggal 07 Januari 2019).

\section{Latar Belakang Perempuan Bekerja di PT.Multi Usaha Raya Kabupaten Sorong}

Hasi penelitian menunjukkan bahwa Ada 3 kegiatan produksi yang banyak mempekerjakan perempuan yaitu, bagian penyusunan dan perbaikan venir, perekatan dan mengempaan kayu lapis, serta pengerjaan akhir kayu lapis. Hal ini menunjukkan bahwa tenaga kerja 


\section{Noken Volume 5 ( 1 ) Halaman : 43-52 2019}

perempuan mempunyai peranan yang cukup besar dalam kegiatan produksi kayu lapis. Selain itu, industri kayu lapis merupakan lapangan kerja yang sesuai dengan perempuan.

Umur rata-rata tenaga kerja perempuan adalah 24 tahun atau berkisar antara 18 tahun sampai dengan 50 tahun. Hal ini berarti peranan perempuan di bidang produksi kayu lapis berasal dari kelompok usia produktif.

Sebagian besar pabrik kayu lapis menerapkan pergiliran kerja panjang yaitu 10 jam kerja dan 2 jam istirahat, atau 2 pergiliran kerja perhari yaitu siang dan malam hari. Situasi kerja demikian menuntut agar kondisi fisik tenaga kerja perempuan adalah cukup kuat. Kondisi fisik demikian mungkin kurang dimiliki oleh perempuan dari golongan usia diluar kisaran usia produktif.

Tingkat pendidikan formal tenaga kerja perempuan berkisar antara Sekolah Dasar (SD), Sekolah Lanjutan Tingkat Pertama (SLTP), dan Sekolah Lanjutan Tingkat Atas (SLTA). Dari hasil penelitian diketahui bahwa $34 \%$ tenaga kerja perempuan pendidikan SD, $29 \%$ berpendidikan SLTP, dan 33\% pendidikan SLTA.
Selain itu upah adalah harga jasa tenaga kerja yang dipasok oleh pekerja per satuan waktu. Oleh karena itu, upah memiliki peranan langsung dengan jam kerja yang di tawarkan oleh tenaga kerja. Untuk sebagian besar tenaga kerja, upah merupakan motivasi dasar yang mendorong tenaga kerja untuk bekerja. Makin tinggi tingkat upah maka makin banyak jam kerja yang di tawarkan oleh tenaga kerja, dalam batas tertentu. Dari hasil penelitian di ketahui bahwa upah pokok tenaga kerja dengan pergiliran kerja normal perempuan berkisar antara Rp.113.000 perhari. Ratarata upah pokok tenaga kerja perempuan yang bekerja dengan pergiliran kerja panjang adalah Rp.152.000 per hari, Hal ini berarti upah pokok tenaga kerja perempuan yang bekerja dengan pergiliran kerja panjang lebih tinggi dari pada bekerja dengan pergiliran kerja normal.

Berikut adalah hasil wawancara kepada responden terkait latar belakang mereka bekerja di perusahaan di PT. Multi Usaha Raya:

Wawancara dengan Ibu berinisial "SW" umur 46 tahun "Ibu "SW" bekerja di perusahaan PT.Multi Usaha Raya karena perusahaan dapat menerima kariyawan dengan persyaratan salah satunya adalah 


\section{Noken Volume 5 ( 1 ) Halaman : 43-52 2019}

ijazah minimal SD sederajat ibu sudah dapat di terima kerja, cara kerjanya juga tidak begitu sulit menurut ibu SW, dan gajinyapun lumayan untuk memenuhi kebutuhan keluarga. Karena ijazah terakhir ibu SW hanya ijazah SD oleh sebab itu ibu SW merasa hanya menjadi buruh di perusahaan PT. Multi Usaha Raya ibu dapat bekerja dengan memperoleh penghasilan tetap dan lumayan besar menurutnya". (Tanggal 07 januari 2019)

Wawancara dengan ibu "AT" umur 32 tahun "Alasan ibu "AT" bekerja di perusahaan PT.Multi Usaha Raya sebab banyak tetangganya mengajak ibu "AT" untuk ikut bekerja bersama mereka. katanya ingin coba-coba saja tapi saat masuk kerja sekiranya sebulan ibu "AT" merasa nyaman karena selain dapat banyak teman kerjanya juga mudah pendapatan yang di hasilkannya

\section{KESIMPULAN}

Dari hasil penelitian menunjukkan bahwa hampir seluruh karyawan perempuan di perusahaan PT. Multi Usaha Raya merupakan ibu rumah tangga. Meski harus bekerja perannya sebagai istri dan ibu dalam keluarga tidak mereka abaikan, dari dini hari mereka sudah harus bangun untuk menyiapkan seluruh keperluan suaminya juga sangat membantu menambah penghasilan suaminya oleh sebab itu dia memutuskan untuk lanjut bekerja di PT. Multi Usaha Raya”. (Tanggal 07 januari 2019).

Wawancara dengan ibu "PA" umur 19 tahun "Alasan Ibu "P" bekerja di perusahaan PT.Multi Usaha Raya adalah untuk mencari pengalaman kerja dan mengisi waktu kosongnya karena ibu PA belum memiliki anak waktunya lebih banyak bersantai-santai saja di rumah karena itulah ibu PA memutuskan untuk bekerja dan juga karena gaji tenaga perempuan di pabrik tersebut yang dianggap lumayan baginya, untuk membantu suami memenuhi kebutuhan ekonomi rumah tangga". (Tanggal 07 januari 2019).

sebelum berangkat bekerja dan anaknya sebelum berangkat sekolah seperti menyiapkan pakaian seragam dan sarapan untuk anak dan suaminya, setelah itu membersihkan rumah lalu mulai untuk berangkat kerja pagi harinya hingga petang demi keluarga mereka. seperti tidak ada kata lelah bagi mereka bilamana pada waktu libur kerja, mereka juga punya rutinitas lain untuk mengisi waktu kosong mereka yaitu 


\section{Noken Volume 5 ( 1 ) Halaman : 43-52 2019}

dengan mengikuti pengajian mingguan, berkebun membantu suami bahkan ada yang berjualan untuk menambah penghasilan demi keluarga mereka.

Perempuan memang mempunyai kelebihan yang unik di banding dengan lakilaki, seperti etos kerja tinggi, ulet, sabar dan teliti. Keterlibatan perempuan dalam meningkatkan perekonomian keluarga tidak diragukan lagi. perempuan yang hidup di daerah persawahan, mereka akan pergi ke sawah, jika berada di daerah yang ramai nuansa perdagangan, maka perempuan yang memenuhi pasar sebagai pedagang. jika dekat dengan kawasan industri, maka perempuan paling banyak menjadi karyawan. Perempuan dapat melakukan dua peran sekaligus yaitu perannya sebagai ibu rumah tangga maupun sebagai pekerja untuk menambah perekonomian keluarganya. Perempuan mampu menyelesaikan tugasnya sebagai ibu dari anak-anaknya dan istri dari suaminya.

Selain itu Suatu proses pengambilan keputusan perempuan untuk bekerja di dasari oleh macam-macam alasan di antaranya karena untuk meningkatkan kesejahteraan ekonomi ataupun untuk memenuhi kebutuhan sekolah anak-anaknya, keinginan untuk memiliki teman yang lebih banyak, mengejar status, dan senang dengan pekerjaan.

Latar belakang perempuan bekerja di perusahaan PT. Multi Usaha Raya adalah karena aspek-aspek kebijakan dari perusahaan seperti: tingkat pendidikan formal tenaga kerja perempuan berkisar antara Sekolah Dasar (SD), Sekolah Lanjutan Tingkat Pertama (SLTP), dan Sekolah Lanjutan Tingkat Atas (SLTA). Dari hasil penelitian diketahui bahwa $34 \%$ tenaga kerja perempuan pendidikan SD, $29 \%$ berpendidikan SLTP, dan 33\% pendidikan SLTA.

Selain itu upah adalah harga jasa tenaga kerja yang dipasok oleh pekerja per satuan waktu. Oleh karena itu, upah memiliki peranan langsung dengan jam kerja yang di tawarkan oleh tenaga kerja. Untuk sebagian besar tenaga kerja, upah merupakan motivasi dasar yang mendorong tenaga kerja untuk bekerja. Makin tinggi tingkat upah maka makin banyak jam kerja yang di tawarkan oleh tenaga kerja, dalam batas tertentu. Dari hasil penelitian di ketahui bahwa upah pokok tenaga kerja dengan pergiliran kerja normal perempuan berkisar antara Rp.113.000 perhari. Ratarata upah pokok tenaga kerja perempuan yang bekerja dengan pergiliran kerja 


\section{Noken Volume 5 ( 1 ) Halaman : 43-52 2019}

panjang adalah Rp.152.000 per hari, Hal ini berarti upah pokok tenaga kerja perempuan yang bekerja dengan pergiliran kerja panjang lebih tinggi dari pada bekerja dengan pergiliran kerja normal.

Adapun Pendapatan tenaga kerja adalah upah tenaga kerja di kali jumlah jam kerja. Pendapatan tenaga kerja dengan demikian tergantung pada tingkat upah dan jumlah jam kerja. Kadangkala masih ada jenis pendapatan yang di terima dalam bentuk lain, misalnya dalam bentuk natura seperti beras, gula dan sebagainya. Sementara itu, penghasilan tenaga kerja merupakan jumlah seluruh pendapatan selama periode waktu tertentu (termasuk DAFTAR PUSTAKA

BKKNBN. 2002. Analisis Gender, BKKBN

Pusat, Jakarta.

John M. Echols dan Hasan Shadily. 1992. Kamus Inggris Indonesi, Gramedia Jakarta. bunga tabungan,deviden,pembayaran transfer, dan lain-lain).

Di pabrik kayu lapis, pendapatan tenaga kerja per bulan pada umumnya terdiri atas upah pokok, asuransi, tenaga kerja, uang makan, uang transport (pengganti fasilitas antar jemput pegawai), dan uang lembur. Selain itu, tenaga kerja masih memperoleh pelayanan kesehatan dari perusahaan, dan jaminan sosial tenaga kerja (jamsostek) pada saat dibutuhkan. secara teratur tenaga kerja juga menerima tunjangan hari raya (THR) yang besarnya rata-rata sama dengan upah pokok per bulan.

Julia C. Mosse, 2002. Gender dan Pembangunan, Pustaka Pelajar, Yogyakarta.

Kabupaten Sorong BPS. 2017. Kabupaten Sorong Dalam Angka 2017, BPS Kabupaten Sorong.

Mansour Fakih. 2002. Analisis Gender dan Transformasi Sosial, Pustaka Pelajar, Yogyakarta. 


\section{Noken Volume 5 ( 1 ) Halaman : 43-52 2019}

Loekman Soetrisno. 1997. Kemiskinan Perempuan dan Pemberdayaan, Kanisius, Yogyakarta.

W.J.S Purwadarminta. 1976. Kamus Umum Bahasa Indonesia, Balai Pustaka, Jakarta.

Mas'ud Khasan abdul Qohar. 1998. Kamus Ilmiah Populer, Penerbit Bintang Pelajar, Jakarta.

Pringgodigdo. 1973. Ensiklopedi Umum, Yayasan Kanisius, Yogyakarta.

Ratna Saptar. 1997. Perempuan Kerja Dan Perubahan Sosial, PT.Anem Kosong Anem, Jakarta.

Ryadi Gunawan.1993. Transformasi Sosial Politik: Antaran Demokratisasi dan Stabilitas, dalam M. Masyhur Amin (ed) Agama, Demokrasi dan Transformasi Sosial, KPSM, Yogyakarta.

Sugiyono, 2013, Metodologi penelitian Kuantitatif, Kualitatif Dan $R \& D$, ALFABETA, Bandung.

Suratiah dkk,1999. Delima Perempuan Antara Industri Rumah Tangga dan Aktifitas Domestik, Aditya Media, Yogyakarta. 